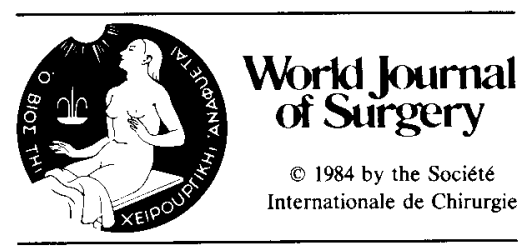

\title{
Prevalence of Diffuse Pancreatic Beta Islet Cell Disease with Hyperinsulinism: Problems in Recognition and Management
}

\author{
Timothy S. Harrison, M.D., Stefan S. Fajans, M.D., John C. Floyd, Jr., M.D., Norman W. Thompson, \\ M.D., Dennis A. Rasbach, M.D., Richard J. Santen, M.D., and Cynthia Cohen, M.D. \\ Departments of Surgery, Internal Medicine (Endocrinology), and Pathology, The Milton S. Hershey Medical Center; The \\ Pennsylvania State University College of Medicine, Hershey, Pennsylvania, U.S.A.; and Departments of Internal Medicine (Division \\ of Endocrinology and Metabolism) and Surgery, The University of Michigan Medical Center, Ann Arbor, Michigan, U.S.A.
}

\begin{abstract}
Among 77 patients with endogenous hyperinsulinism seen in $\mathbf{2}$ medical centers, diffuse islet cell disease accounted for $17(22 \%)$ patients. Since diffuse islet cell disease poses special problems in management, its prevalence is emphasized in this report.

Among these patients with diffuse islet cell disease, there were 11 patients with adenomatosis, 4 with nesidioblastosis, and 2 with islet cell hyperplasia. Six of the 77 patients were found in multiple endocrine neoplasia, type I kindreds; diffuse islet cell disease was documented in 4 of these patients.

We outline principles of management in patients with diffuse islet cell disease. Frozen section microscopy failed to identify nesidioblastosis or islet cell hyperplasia.
\end{abstract}

A continuing problem for surgeons operating on patients with endogenous hyperinsulinism is what to do when no diseased tissue is found at surgery after a preliminary exploration of the pancreas. Solitary beta islet cell adenomas can be overlooked when not palpable; identification of diffuse islet cell

Presented at the International Association of Endocrine Surgeons at Hamburg, September 1983.

Supported in part by U.S. Public Health Service Grants AM-02244 and AM-0888; and NIH-5 M01 RR-42 General Clinical Research Centers, The University of Michigan, Ann Arbor, Michigan.

Reprint requests: Timothy S. Harrison, M.D., Professor of Surgery and Physiology, The Milton S. Hershey Medical Center, The Pennsylvania State University College of Medicine, P.O. Box 850, Hershey, Pennsylvania 17033, U.S.A. disease poses many problems. We recognize 3 major diffuse islet cell disorders associated with hyperinsulinism: beta islet cell adenomatosis, which can often be recognized by the operating surgeon; nesidioblastosis, and pancreatic beta cell hyperplasia, both of which defy operative recognition. In addition, multiple macroadenomas may or may not co-exist with microadenomatosis or hyperplasia in certain patients with hyperinsulinism. Multifocal islet cell disorders are particularly frequent in patients with multiple endocrine neoplasia, type I (MEN I). Other than to recognize its occurrence, we do not include in this review of diffuse islet cell disorders an analysis of sporadic beta islet cell carcinoma. In many patients, the results of preoperative transhepatic venous catheterization (THVC) should draw attention to the possible presence of diffuse islet cell disease.

\section{Case Material}

Seventy-seven patients with hyperinsulinism were cared for, 69 at the University of Michigan Medical Center since 1960 and 8 at The Milton S. Hershey Medical Center of The Pennsylvania State University since 1973. Infants and young children under the age of 9 years are not included in this report.

\section{Solitary Islet Cell Adenoma}

While not the major focus of this report, solitary hyperfunctioning islet cell adenoma was the most 
Table 1. Endogenous hyperinsulinism.

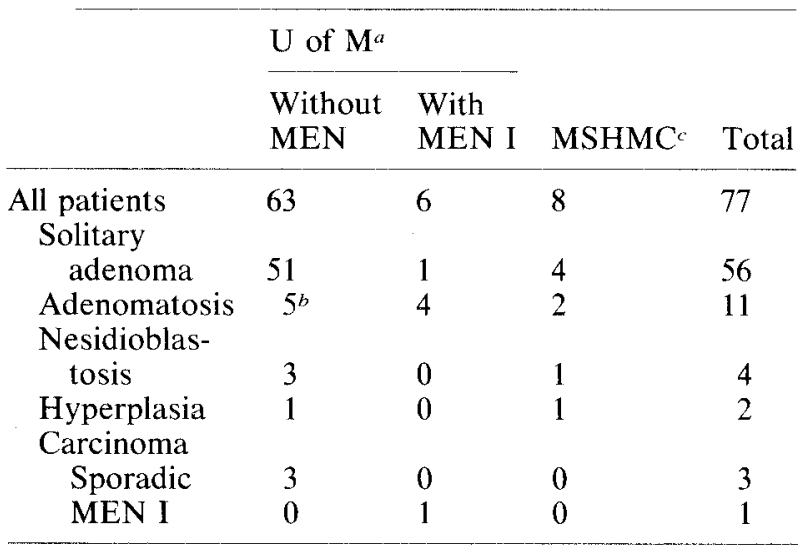

aniversity of Michigan Medical Center.

${ }^{b}$ One patient with macroadenomas only, 1 patient with macroadenomas + microadenomatosis, 3 patients with microadenomas + hyperplasia.

cMilton S. Hershey Medical Center, Pennsylvania State University College of Medicine.

frequent lesion seen-56 $(73 \%)$ of the 77 patients (Table 1). In 1 patient, the adenoma was not found in a blind distal $85 \%$ pancreatic resection. For 16 years her hyperinsulinism has been well controlled with $150 \mathrm{mg}$ of diazoxide daily.

Two other patients with solitary adenoma deserve special comment. One, a 60-year-old male, had a $10-\mathrm{g}$ adenoma removed from the pancreatic tail. There was microadenomatosis in the pancreas surrounding the lesion but it is thought to be of no functional significance since the patient has required no treatment for 9 years since surgery. Plasma glucose, plasma insulin, and insulin/glucose ratios are normal during repeated 72 -hour fasts.

The other solitary adenoma of special interest was in a patient with MEN I. Her plasma glucose and insulin levels and insulin/glucose ratios are normal since removal of her solitary adenoma 10 years ago.

\section{Adenomatosis}

Eleven (14\%) of 77 patients had adenomatosis (Table 1). In 4 patients the diagnosis was made intraoperatively by the recognition of multiple macroadenomas and confirmed by frozen section microscopy. In one additional patient the diagnosis was made by the endocrinologist in the operating room while sectioning an $80 \%$ distally resected pancreatic segment (Table 2). He saw multiple small adenomas, and microscopic adenomatosis was confirmed by frozen section. Hyperinsulinism had persisted following our initial operation with removal of a $2.5-\mathrm{cm}$ diameter adenoma thought to be a solitary adenoma in the neck of the pancreas. Eighty
Table 2. Successful intraoperative identification at first exploration.

\begin{tabular}{ll}
\hline Adenomatosis & $5 / 11$ \\
Nesidioblastosis & $0 / 4$ \\
Hyperplasia & $0 / 2$ \\
\hline
\end{tabular}

Table 3. Endogenous hyperinsulinism: Multiple endocrine neoplasia I [6/77 patients $(8 \%)]$.

$\begin{array}{ll}\text { Solitary adenoma } & 1 \\ \text { Double adenoma } & 2 \\ \text { Adenoma plus microadenomatosis } & 1 \\ \text { Adenoma plus hyperplasia } & 1 \\ \text { Multicentric beta cell carcinoma } & 1\end{array}$

percent pancreatectomy has resulted in an acceptable but by no means ideal course in that $100 \mathrm{mg}$ diazoxide is required twice daily and fasting plasma glucose levels 10 years postoperatively are often around $50 \mathrm{mg} / 100 \mathrm{ml}$.

In a 20 -year-old female, a $1.0-\mathrm{cm}$ diameter adenoma was removed from the pancreatic head in the belief that this was the patient's only lesion. Since surgery, she has been able to control symptoms of hypoglycemia on diet alone, but abnormal plasma insulin/glucose ratios persist in excess of 0.3 [1]. During the first trimester of a recent pregnancy, occasional overnight fasting plasma glucose levels were between 40 and $50 \mathrm{mg} / 100 \mathrm{ml}$. As the pregnancy progressed, a typical fasting plasma glucose of $94 \mathrm{mg} / 100 \mathrm{ml}$ and concomitant insulin level of $75 \mu \mathrm{U} / \mathrm{ml}$ gave an insulin/glucose ratio of 0.8 . Hypoglycemia in the $40 \mathrm{mg} / 100 \mathrm{ml}$ range at delivery has subsided and the patient remains well controlled on diet alone. The diagnosis of adenomatosis is presumptive in this patient and she is the only one in whom there is no microscopic confirmation.

There have been other lesions in the remaining 5 patients with sporadically occurring adenomatosis. One patient had a macroscopic adenoma plus microadenomatosis and 4 had visible adenomas plus hyperplasia.

Patients with adenomatosis have received 75-85\% distal pancreatectomy and vary from requiring no treatment postoperatively to requiring as much as $200 \mathrm{mg}$ diazoxide daily to prevent symptomatic hypoglycemia.

Four of the 11 adenomatosis patients are from 3 MEN I kindreds and had differing lesions associated with their adenomatosis (Tables 1 and 3 ). In two, 2 macroadenomas were present, in another a single macroadenoma co-existed with microadenomatosis, and in another multiple adenomas coexisted with islet cell hyperplasia. These patients 
have all responded adequately to $75-85 \%$ pancreatectomy.

\section{Nesidioblastosis}

In our 4 patients with nesidioblastosis, there was no evidence of MEN I (Tables 1 and 3). Distal 75-85\% pancreatectomy was done but in none did frozen section microscopy identify the lesion (Table 2). Three of these patients have been reported before [2]. Two patients were cared for before the availability of transhepatic portal venous sampling. One was an 11-year-old girl with a 2-year history of hypoglycemia for whom an $80 \%$ blind distal pancreatectomy was done. While she leads an active life as a college student, medical control of her hyperinsulinism with diazoxide is not ideal because of erratic fasting plasma glucose levels often below $50 \mathrm{mg} / 100 \mathrm{ml}$. A 47 -year-old man was cured by a $70-80 \%$ distal pancreatectomy. Plasma glucose, plasma insulin, and insulin-to-glucose ratios are normal during a 72-hour fast 6 years postoperatively.

In a 66-year-old male, results of portal venous sampling done preoperatively were compatible with, but not necessarily diagnostic of, a solitary adenoma in the pancreatic head (Fig. 1). In spite of vigorous exploration of the pancreatic head, an adenoma was not found. Eighty percent blind distal pancreatectomy was done after a negative frozen section of the pancreatic tail. On permanent section microscopy there was well-defined nesidioblastosis throughout the resected specimen along with a few normal islets. The granules of the nesidioblastosis cells when stained with a specific immuno-peroxidase technique were positive for insulin. A small adenoma in the resected pancreas contains glucagon on immuno-peroxidase stains but no insulin. Postoperatively on diazoxide, $150 \mathrm{mg} 3$ times daily, the patient is improved, but his course is not optimal in that fasting glucose levels are often around $50 \mathrm{mg} / 100 \mathrm{ml}$. He manages his diet with 3 daily feedings and feels no need to eat at night. Recently, a random postprandial plasma glucose of $138 \mathrm{mg} / 100 \mathrm{ml}$ was associated with a plasma insulin of $6 \mu \mathrm{U} / \mathrm{ml}$.

In one 20-year-old patient with nesidioblastosis, preoperative transhepatic portal venous sampling suggested multifocal islet cell disease. Frozen section microscopy was negative for nesidioblastosis but this lesion was subsequently demonstrated with immuno-peroxidase technique.

\section{Islet Cell Hyperplasia}

We have seen 2 patients with islet cell hyperplasia (Table 1). A 53-year-old female before referral to us

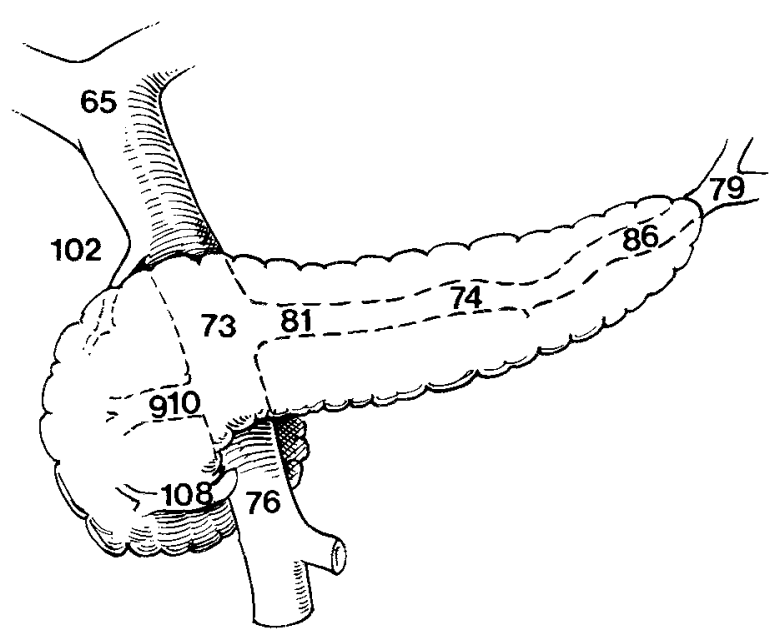

Fig. 1. Plasma insulin values in $\mu \mathrm{U} / 100 \mathrm{ml}$ during transhepatic venous catheterization (THVC) in a patient with proven nesidioblastosis. The preoperative interpretation of a solitary adenoma in the pancreatic head may not be correct. An adenoma could not be found. Concomitant systemic insulin levels are not available for comparison with those obtained during THVC. Mean insulin concentration of values obtained from the splenic vein, superior mesenteric vein, confluence and portal veins is $76(65-86)$ . $\mu \mathrm{U} / \mathrm{ml}$. Venous blood draining the head of the pancreas had concentrations of 108,910 , and $102 \mu \mathrm{U} / \mathrm{ml}$ in 3 separate locations suggesting multifocal hyperinsulinism. Five weeks before this study, systemic venous fasting plasma insulins were 57 and 79 .

had an $80 \%$ blind distal pancreatectomy, and islet cell hyperplasia was recognized on permanent section microscopy. Her hyperinsulinism has been controlled on 200-250 mg diazoxide daily for 8 years.

The second patient with hyperplasia was in her thirties when treated by $70 \%$ pancreatic resection over 20 years ago. She has been asymptomatic and remains euglycemic.

In both patients with hyperplasia, frozen section microscopy did not show diffuse islet cell disease.

\section{Multiple Endocrine Neoplasia, Type I}

There are 6 patients from 3 kindreds with MEN I (Table 3 ). One patient had a solitary adenoma. Another patient with multicentric islet cell carcinoma had en-bloc distal hemipancreatectomy including involved lymph nodes and a focus of tumor toward the tail of the pancreas. An additional tumor was removed from the pancreatic head. Fifteen years since his surgery, he continues to do well with no hypoglycemic attacks and normal fasting insulin/ glucose ratios. 
Table 4. Prevalence of diffuse islet cell disease.

\begin{tabular}{llll}
\hline & $\mathrm{U}$ of $\mathrm{M}^{a}$ & $\mathrm{MSHMC}^{b}$ & Total \\
\hline All patients & $13 / 69$ & $4 / 8$ & $17 / 77(22 \%)$ \\
Adenomatosis & 9 & 2 & 11 \\
Nesidioblastosis & 3 & 1 & 4 \\
Hyperplasia & 1 & 1 & 2
\end{tabular}

a University of Michigan Medical Center.

${ }^{b}$ Milton S. Hershey Medical Center, Pennsylvania State University College of Medicine.

\section{Discussion}

In this combined series from 2 medical centers, 17 $(22 \%)$ of 77 patients with endogenous hyperinsulinism had multifocal islet cell disease (Table 4).

Multifocal islet cell disease defies easy or exact pathologic classification for a number of reasons. Some patients may have more than one beta islet cell abnormality and when confronted with this, we have classified the case according to the lesion that is most easily apparent. Some authors believe that the various beta cell diseases described have a common origin and that morphologic separation of distinct pathological entities ignores this fact. Gabbay has postulated that adenomas, focal hyperplastic adenomatosis, islet cell hyperplasia, islet hypertrophy, and nesidioblastosis may all be an expression of one and the same basic defect and had proposed the term islet cell dysmaturation syndrome [3]. Jaffe et al. defined and described various beta cell pathological entities found in hyperinsulinemic hypoglycemia of infancy [4].

From a practical standpoint, preoperative identification of multifocal islet cell disease in the patient with hyperinsulinism is of great help in planning operative intervention. The recent development of percutaneous transhepatic portal venous sampling permits differentiation of localized from multifocal hyperinsulinism $[2,5,6]$. More experience with this technique is required before its true role and accuracy is clear. Certain circumstances make interpretation of transhepatic portal venous sampling difficult. Nesidioblastosis may be diffuse or focal. Thus greater focal elevations of insulin concentration may occur in some tributaries of the portal venous system than in others. Hypersecretion of insulin is not constant and intermittent fluctuation in insulin levels occurs in patients with localized or diffuse islet cell hyperfunction. Thus it is essential to have concomitant systemic arterial or venous blood samples drawn at the time of portal venous samplings [6]. We would, for example, be better able to interpret the portal venous catheterization values shown in Fig. 1 if simultaneous systemic insulin levels were available. For these rea- sons, results of transhepatic venous catheterization may give the appearance of indicating localized disease (adenoma) when diffuse disease is present. Also, the high prevalence of multifocal or diffuse islet cell disease in patients with hyperinsulinism who have MEN I or who are members of such kindreds should lead one to assume preoperatively that more than one focal lesion is present.

In Frantz's original description of beta cell adenomatosis in 1944, hypoglycemia persisted if only visible or palpable adenomas were removed [7]. Nesidioblastosis, the original multifocal islet cell disorder to be recognized, was first suggested by Laidlaw in 1938 [8]. In many patients with nesidioblastosis, limited pancreatic resection has proven inadequate on prolonged follow-up. In a patient who has a negative exploration for solitary adenoma, intraoperative real-time ultrasonography may be helpful. LeQuesne is prominent among advocates of primary resection of the pancreatic head if no insulin-secreting disease condition is found in hyperinsulinism [9]. We disagree because of the high likelihood of multifocal islet cell disease when there is no discernible pancreatic islet cell disease at operation. We prefer a $75-85 \%$ distal pancreatectomy as a more restrained alternative associated with an appreciably lower mortality rate. We have described previously our diagnostic criteria and operative treatment of endogenous hyperinsulinism [10]. The single operative death in our series was from a coagulopathy 1 month after removal of a single adenoma in a 64-year-old male. He was the oldest patient on whom we have operated.

The variety of multifocal islet cell pathological conditions is well exemplified in our patients with and without MEN I. Other islet cell endocrinologic abnormalities may co-exist with hyperinsulinism in patients with MEN I and this is the subject of a separate report [11]. Conceivably other forms of islet cell hyperplasia may co-exist with endogenous hyperinsulinism from a solitary beta cell adenoma. This could lead to unnecessary $80 \%$ pancreatic dissection when only adenoma excision is needed to control hyperinsulinism. Intraoperative immunocytochemistry is a possible solution to this problem but we have no experience with it.

For the majority of patients with hyperinsulinism due to multifocal islet cell disease, there is no cure of hyperinsulinism from $70-80 \%$ pancreatic resection. Frequently, hyperinsulinism will persist after subtotal pancreatic resection for functioning, multifocal islet cell disease. However, the patients do become more manageable on drug regimens which typically were ineffective before pancreatic resection. Surgery for endogenous hyperinsulinism continues to require thoughtful collaboration between endocrinologists, radiologists, pathologists, 
and surgeons and must be highly individualized to pathological and functional subtleties of each patient.

\section{Résumé}

Chez 77 malades, provenant de 2 centres médicaux, qui présentaient un hyperinsulinisme endogène, 17 cas de lésions diffuses des îlots de Langerhans ont été dénombrés. Ce fait est donc loin d'être exceptionnel et cette étude a pour but de le souligner.

Parmi ces 17 malades, 11 présentaient des adénomes multiples (adénomatoses), 4 des nésidoblastomes (anomalies tissulaires multifocales), 2 des hyperplasies cellulaires insulaires. Chez ces 77 malades, 6 cas de MEN type I furent individualisés, 4 d'entre eux présentaient une maladie insulaire diffuse.

Les auteurs, forts de cette expériences insistent sur les principes du traitement de ce type d'affection. Ils insistent sur le fait que l'étude histologique extemporanée ne permet pas d'identifier les nésidoblastomes et les hyperplasies cellulaires insulaires et que dans $70 \%-80 \%$ des cas les résections pancréatiques ne permettent pas d'obtenir la guérison.

\section{Resumen}

Un problema constante para el cirujano que opera pacientes con hiperinsulinismo endógeno es el de qué hacer cuando no se encuentre patología en el curso de la operación una vez realizada la exploración preliminar del páncreas. Los adenomas solitarios de células beta pueden pasar desapercibidos cuando no son palpables; la identificación de la enfermedad difusa de las células insulares plantea muchos problemas. Reconocemos tres alteraciones principales de tipo difuso: adenomatosis de células beta, nesidioblastosis e hiperplasia pancreática de células beta. Además, múltiples macroadenomas pueden coexistir o no con microadenomatosis o con hiperplasia en ciertos pacientes con hiperinsulinismo. Los desórdenes de células insulares de tipo multifocal son particularmente frecuentes en pacientes con Neoplasia Endocrina Múltiple Tipo I.

Entre 77 pacientes con hiperinsulinismo endógeno observados en dos centros médicos, la enfermedad de células insulares de tipo difuso es- tuvo presente en 17 pacientes (22\%). Teniendo en cuenta que la enfermedad de células insulares de tipo difuso plantea problemas especiales en cuanto a su manejo, este informe hace énfasis en lo relativo a su prevalencia.

En el grupo de pacientes con enfermedad de células insulares de tipo difuso se encontraron 11 pacientes con adenomatosis, cuatro con nesidioblastosis y dos con hiperplasia de células insulares. Seis de los 77 pacientes fueron hallados en familiares con Neoplasia Endocrina Múltiple Tipo I; la enfermedad difusa de células insulares fue documentada en cuatro.

Se presentan los principios de manejo en pacientes con enfermedad de células insulares de tipo difuso. La miscroscopía de cortes por congelación falló en la identificación de la nesidioblastosis o la hiperplasia de células insulares.

\section{References}

1. Harrison, T.S., Santen, R.J., Maruca, J.: Calcium stimulating test in the evaluation of insulin-secreting pancreatic islet cell tumors: Case Reports. Milit. Med. 146:103, 1981

2. Harness, J.K., Geelhoed, G.W., Thompson, N.W.: Nesidioblastosis in adults. Arch. Surg. 116:575, 1981

3. Gabbay, J.H.: Case records of the Massachusetts General Hospital. Weekly clinic pathological exercises: Case 30, 1978. N. Engl. J. Med. 299:241, 1978

4. Jaffe, R., Hashida, Y., Yunis, E.J.: Pancreatic pathology in hyperinsulinemic hypoglycemia of infancy. Lab. Invest. 42:356, 1980

5. Ingemansson, S., Lunderquist, A., Lundquist, I.: Portal and pancreatic vein catheterization with radioimmunologic determination of insulin. Surg. Gynecol. Obstet. 141:795, 1975

6. Glaser, B., Valtysson, G., Fajans, S.S.: Gastrointestinal/pancreatic hormone concentrations in the portal venous system of nine patients with organic hyperinsulinism. Metabolism 30:1001, 1981

7. Frantz, V.K.: Adenomatosis of islet cells with hyperinsulinism. Ann. Surg. 119:824, 1944

8. Laidlaw, G.F.: Nesidioblastoma, the islet tumor of the pancreas. Am. J. Pathol. 14:125, 1938

9. Mengoli, L., LeQuesne, L.P.: Blind pancreatic resection for suspected insulinoma: A review of the problem. Br. J. Surg. 54:749, 1967

10. Harrison, T.S., Child, G.G., III, Fry, W.J.: Current surgical management of functioning islet cell tumors of the pancreas. Ann. Surg. 178:485, 1973

11. Thompson, N.W., Lloyd, R., Vinik, A.I.: MEN I pancreas: A histological and immunohistochemical study. World J. Surg. 8:561, 1984 